\title{
Introducing Technical \& Vocational Education and Training (TVET) in the Secondary Schools in Nepal: Opportunities and Challenges
}

\author{
Chet Nath Kanel \\ $\mathrm{PhD}$ Scholar in Development Studies, Kathmandu University, Hattiban, Lalitpur, Nepal \\ Email for correspondence: chetnathkanel@gmail.com
}

\begin{abstract}
Nepal's education sector is striving for producing quality human resources for the country. However, due to lack of appropriate policy, priority and curricula, the efforts have been less effective. Education sector has also been a subject of criticism due to mismanagement of the 'products' and the industrydemands. Taking these matters into considerations, Government of Nepal is trying to introduce the TVET in secondary education (9-12) system as a pilot-basis. This article has explored some of the critical issues associated with the intention of introducing TVET, its demand and supply-sides debates, challenges as well as opportunities in expanding TVET in Nepalese secondary education system. Literature review, some expert-interviews and reflection of personal experiences are the key methods of information generation for this article. The main conclusion of this article is that the TVET system in Nepal has very high demand to produce the required and quality human resources in Nepal. There are ample opportunities in introducing the expanding of TVET in Nepal. However, key learning from 99-piloted schools should be main basis to take further steps visualizing the feasibility, employability and sustainability from students, schools, and schools' perspectives. Even after the School Sector Reform Program (SSRP), the initiative of introducing TVET in all secondary schools of Nepal should continue.
\end{abstract}

Key words: Technical and Vocational Education and Training, Secondary schools, Quality, Employability, Piloting

\section{Introduction}

Nepal's education sector has been facing a challenge of producing quality and employable human resources required for the country. This debate is continuing for a long time (Sharma, 2010; Sharma, 2014;
Wagley, 2014a). Even the first Education Commission (The 'Wood Commission') report highlighted the need of serious focus on producing 'skillful' and 'employable' students proposing some technical and vocational subjects from class 6 to 10 (Table 1). 
However, for a long period, Nepal has been testing and re-testing the education systems and new models in the name of "educational improvement" mostly dominated by western education systems (Bist, 1991).

\section{Table 1: Curriculum proposed in the Wood Commission Report 1954 AD (2011 BS)}

\begin{tabular}{|c|c|c|c|}
\hline Class $6 \& 7$ & Class 8 & Class 9-10 & Remarks \\
\hline $\begin{array}{l}\text { - } \text { Nepali } \\
\text { - Sociology, } \\
\text { - Practical Science } \\
\text { - Practical Math } \\
\text { - Physical health } \\
\text { education }\end{array}$ & $\begin{array}{l}\text { - } \text { Nepali } \\
\text { - Sociology, } \\
\text { - Practical Math } \\
\text { - Physical health } \\
\text { education }\end{array}$ & $\begin{array}{l}\text { - Nepali } \\
\text { - Sociology, } \\
\text { - Physical health } \\
\text { education }\end{array}$ & $\begin{array}{l}\text { Focus on main \& general } \\
\text { education, health, morality }\end{array}$ \\
\hline Two vocational subjects & Two vocational subjects & Three vocational subjects & $\begin{array}{l}\text { Emphasis on occupation/ } \\
\text { job-focused education }\end{array}$ \\
\hline $\begin{array}{l}\text { One General Vocational } \\
\text { Subject }\end{array}$ & $\begin{array}{l}\text { One General Vocational } \\
\text { Subject }\end{array}$ & $\begin{array}{l}\text { One General Vocational } \\
\text { Subject }\end{array}$ & \\
\hline $\begin{array}{l}\text { Vocational Subjects } \\
\text { 1) Teaching 2) Medical } \\
\text { 9) Industrial subject }\end{array}$ & (1) & (2) & \\
\hline
\end{tabular}

(Source: Makalu Publisher, 2070 BS).

\section{Objective}

The main objective of this short article is to explore the answers of two pertinent questions:

i) How and why the idea of introducing technical \& vocational education and training (TVET) is emerging, and,

ii) Is it possible to (sustainably) introduce the TVET in secondary schools throughout Nepal?

\section{Methodology}

This article is primarily based on literature review. However, to get first hand information, some opinions of experts and educational professionals have also been collected. In addition, as a technical student, I have also reflected my own experiences and feelings. More importantly, personal experiences from a head-teacher of a Kathmandu-based (higher) secondary school-- where TVET (Engineering discipline) is being run for the last 2 years-have been incorporated.

\section{Study findings}

Emergence of ideas to provide TVET in schools

Education experts have raised their continued voices over the need of concentrating on the production of qualified students who could be easily 'absorbed' by the job-markets There is no doubt that skillful people are always in the high priority of employers. The more a person has professional and vocational skills, the more chances are there for her/him getting a job or being self-employed. Despite this, very little progress has been made so far in Nepal.

Several Education Commissions and Committees were formed to study, suggest and improve the education system of Nepal; however, our education system has not been able to come at par with other south Asian countries. This is a big challenge despite high spending on education (for example, in the FY 2071/71 alone, the education budget of the country is about 86 billion rupees) (MoF, 2014). In the New Education Plan (BS 2028), efforts were made to launch vocational education in schools introducing 
pre-vocational (class 6 and 7) and vocational subjects (class 9-10). However, that did not continue for a long period. (Note: I was also one of the products of such 'New Education Plan' implemented during the Panchayat Era).

In response to addressing the recommendations and suggestions of various commissions and committees, particularly after the recommendations made by the (latest) High Level National Education Committee (HLNEC) in 1998; and based on past experiences (gained during Panchayat System), Nepal government decided to launch a School Sector Reform Program (SSRP) from 2009 to 2014 (recently this has been extended up to 2017) (MoE, 2009; MoE, 2014). SSRP has given due importance in implementing TVET in schools on piloting basis with a vision to continue beyond the project period. This has particularly focused on testing the curriculum in 100 schools (with about 15 million dollar budget) so that learning would guide in devolving new systems and modalities for further improvement.

The HLNEC, 1998 proposed that, among others, "provide technical education and vocational skills to illiterate people to SLC-level". Accordingly, under the SSRP, a provision has been made to introduce TVET in secondary schools after holding a piloting in 100 selected secondary schools throughout the country (74 districts covered). At present 99 schools have been piloted with TVET subjects and they are first time giving SLC exams with TEVT subjects in the month of Chaitra 2071 (Dr. Lava Deo Awasthi, Director General of DEO, personal communication, $16^{\text {th }}$ Jan 2015). Similarly, according to him, for the first time, their performance will be judged with "Letter Grading system: e.g. A, B, C, D, E)" instead of percentages. However, this system is heavily criticized due to poor preparation (Wagley, 2014b).

\section{Should TVET be provided in secondary schools in Nepal?}

The interest, intent and plan of the government is clear. There are no doubts that introducing TVET in secondary level education is not a worth. Furthermore, the need of the nation is totally focused on human resources with 'technical and professional' skills- no matter in which discipline they want to be equipped: general professional skills, technical skills, vocational skills or any other (such as- business skill etc.).

Despite our huge investment in education, we have still a lot to in order do increase the enrolment rate and 'survival' rates in schools. For instance, till 2013, we have achieved only $69.4 \%$ survival rate in class 8 and the pass-out rate of the same grade is $60.8 \%$ (NPC, 2014, p. 136). Similarly, survival rate at class 10 , it is just $15 \%$ out of which only about $50 \%$ or less pass the exams.

Therefore, the need of TVET is more important for the students who leave their academic career after or before SLC. Even, the students having passed the plus 2 level can take advantage of TVET system, because, special vocational skills may lead them towards getting jobs to sustain their livelihoods. Employability of TVET is high (MoE, 2013).

In this connection, I talked to Ms Nanda Kumari Maharjan, Principal, Jana Sewa Higher Secondary School (JSHSS), Panga, Kirtipur (personal interaction on 5th January, 2015), where TVET is being adopted since $2070 \mathrm{BS}$, with 37 students (12 female, 25 male) in class 10 and 36 students in class 9 (12 female, 24 male). These 10 class students are appearing first TVET SLC exam in 2071 BS. JSHSS is one of the 99 schools running (piloting) TVET in Nepal. This is the only school in Kathmandu district implementing TVET under new provision.

According to her, JSHSS is teaching "Electrical Engineering (EE)" course having 6 core subjects under it, including Electricals, Electronics, Drawing, Installation \& Maintenance, Computer, and Workshop Technology. All these subjects have 100 marks each making a total 600 marks of 'technical' subjects; and, remaining 400 marks are covered by other core 'general' subjects including Mathematics, Nepali, English and Science. These all make the TSLC with full marks of 1,000. "The government has been providing 4 technical teachers, out of which, 2 Bachelor level/'Engineer' staff--serving as Secondary- 
level teacher-- and 2 Certificate level or junior level staff (Overseer) with 'Lower secondary-level positions. In addition to their regular salary, they also get Rs. 3,000 /month as an allowance", adds Ms Maharjan.

Among the 5 technical subjects (streams) provided by the government, JSHSS chose the "electrical" engineering subjects. Other schools can choose other subjects based on their local interest, needs and market demands. Other 4 streams are: Civil Engineering, Computer Engineering, Animal Husbandry, and Agriculture.

According to Ms Maharjan, they had a wider consultation with local people/parents and industry in the process of selecting "Electrical Engineering" as the main trade of JSHSS. "There is a huge demand of such trained persons in the locality and our students have already seen the market potentiality", opines she.

Her experiences are positive, optimistic and full of advocacy for continuing the TVET system all over Nepal. Similarly, she suggests the government to continue to invest more on such subjects to create more and more employable cadres in the rural as well as urban areas of Nepal. "No matter they work here or go abroad, they always earn better, their lives become prosperous, and their status of self-reliance becomes more sustainable", she expressed. In my query with Prof. Dr. Tanka Nath Sharma, who is considered as one of the pillars of TVET systems in Nepal, stated that, "The future of TVET is undoubtedly bright, but we need to modify it, as in smaller classes (6-8) only 'soft skills' should be introduced, and form class 9 to 12 students must be equipped with technical and vocational subjects" (personal communication, $4^{\text {th }}$ January 2015).

Dr. Sharma further suggested for a collaborative implementation of such programs with different stakeholders including MoE, DoE, HSEB, CTEVT, FNCCI and local governments. The role of local governments in producing qualified/ capable workforce is much talked in recent times. However, due to absence of elected government, the tie-up of Local Self Governance Act (LSGA) and the Education Act is loosening (Dr. Bhola Prasad Dahal, personal communication, $16^{\text {th }}$ January 2015). In the future, there is possibility of getting supports from local governments to produce skillful human resources from schools/ colleges.

The TVET policy of Nepal (2010) has also emphasized in paying due attention to school level education to produce technical and vocational students making them free from their own choice for going higher studies in the same discipline or starting work in the subjects learned. The NPC's 3year Plan has also highlighted the importance of TVET in our school systems appreciating the achievements of our past educational efforts and also seeking potential partnerships from financial institutions/ private sector, community and government sectors ( can be called 'PPP model') (2014, p. 138).

\section{Challenges ahead}

The intent and motive of the government to continue TVET in secondary schools is obviously praiseworthy as this system has moved towards satisfying the high demands of the youths, parents, job-providers, educationists and so on. However, there are lots of challenges to continue as such. "One of main challenges is to retain the qualified 'technical teachers' in such schools as they have very high potential of getting better jobs in other sectors than teaching", expressed Ms Maharjan. This is a fundamental question as this was the case when I was also a technical student in 1980s in Gulmi district.

In addition, the delay in formulating a new Education Act has caused lots of discrepancies in between Secondary and Higher Secondary Schools. According to previous policies and plans, by 2014 the SLC exam could have merged with class 12 , having a national examination board (NEB) system. But, this has delayed due to absence of new Education Act. Likewise, these first batch TSLC students will need 
similar subjects in class 11 and 12 as well. The government has very recently declared that the TSLC students will get opportunity to continue their 10 plus 2 education in the same subjects throughout the country.

If such is the case, the TSLC students will have the chance to pilot those 10 plus 2 technical and vocational subjects under HSEB system. The lessons learnt through this system would provide the government to make further decision on gradually expanding the TVET education system in other secondary and higher secondary schools. Let's hope there won't be any dilemma in implementing TSLC in Higher Secondary Schools too. The absorption of such mid-level (plus 2) technical persons as 'employee' in the industry sector, and also the 'welcome' of such 'TVET plus 2 graduated students' as 'Bachelor level students' in the technical colleges would signify the real value of TVET education system in Secondary and Higher Secondary levels.

\section{Conclusion}

In conclusion, with the above discussions, it can be said that the introduction of TEVT in the secondary and higher secondary education (9-12) in Nepal is a very good initiative and it must be implemented throughout the country soonest possible. Based on the learning from 99 piloted schools, it must be improved, synchronized adopted in other schools as well. Considering high unemployment rate, high drop-out rate after SLC, and also valuing the essence of such TEVT subjects as a 'preparatory' for further higher studies (Bachelors and Masters level courses). There is a clear fact that if they get chance to continue their higher studies in the same technical fields, they will perform better in their chosen technical/ vocational/ professional subjects. Even if they are unable to pursue higher studies, they will at least be ready to accept any job as a middle-level technical staff with greater possibilities of getting 'better salaries'. Also, they can gain confidence for their self-employment.

Streamlining and synchronizing other higher level study courses, then, is an important task for Nepalese education. In this, Ministry of Education, Department of Education, National Examination Board, CD), CTEVT, HSEB, all universities (through UGC) should work very closely.

In my personal opinion, we should continue the piloting with these 99 schools at least for another 3 years, so that solid experiences can be achieved. By then, hopefully the new Education Act will be in our hand, SSRP's new strategy will come, and most importantly, federal structure of the government will be set. While waiting for all these 'dream' things, we must be vigilant in closely monitoring the performance and documenting 'best' practices from those 99 piloted-schools.

\section{References}

Bhandari, A. (2015). Paisa uthaundai taap ('Manpower agencies are cheating the foreign job-seekers'). Kantipur National Daily, $5^{\text {th }}$ January, 2015 (21 Poush 2071). Kathmandu, Nepal

Bist, D. B. (1991). Fatalism and development: Nepal's struggle for modernization. Delhi: Orient Longman.

GoN (2028 BS). Siksha Ain. $7^{\text {th }}$ Ed., Kathmandu: Government of Nepal.

Koirala, B. N. (2015). Gunastareeya siksha- ke maa lagaani garne? (Quality education: On what to make investment?). Sikshak monthly, Vol. 7, No. 81, Poush 2071 pp. 46-49. (Dec. 2014- Jan. 2015). Kathmandu.

Makalu Publisher (2070 BS). Siksha Aayogkaa Prativedanharoo (Reports of Education $\backslash$ Commission in Nepal). Kathmandu : Makalu Publishers.

MOE (2010). Technical education and vocational training policy, Kathmandu: Ministry of Education- Government of Nepal, 
MOE (2009). School Sector Reform Plan (SSRP) 2009-2015. Kathmandu: Ministry of Education Government of Nepal.

MOE (2013). School Sector Reform Plan (SSRP)

Progress Report, 2013/14. Kathmandu: Ministry of Education- Government of Nepal.

MOE (2014). School Sector Reform Plan (SSRP) Revised Plan 2015-2017. Kathmandu: Ministry of Education- Government of Nepal.

NPC (2014). $13^{\text {th }}$ Periodic Plan 2070/71- 2072/73. Kathmandu: National Planning Commission, Singh Durbar.

Sharma, S.R. (2071 BS). Siksha: Nepalko Sandarva. Dhulikhel- Kavre : Urmila Sharma Dhungel.

Sharma, T.N. (2010). Technical Vocational Education and Training Focusing on Soft Skills in Reference to School Sector Reform in Nepal. TVET Development Journal (CTEVT), 1 (10), 5-17.

Wagley, M. P. (2014a). Bidhyalaya Siksha ki Karkhana ('School education or factories?'). Kantipur National Daily, $10^{\text {th }}$ Chaitra 2070 (March 2014). Kathmandu.

Wagley, M. P. (2014b). SLC maa akshar grading pranalee ('Letter grading system in SLC'). Kantipur National Daily, $9^{\text {th }}$ Poush 2071 (24 Dec. 2014). Kathmandu. 